
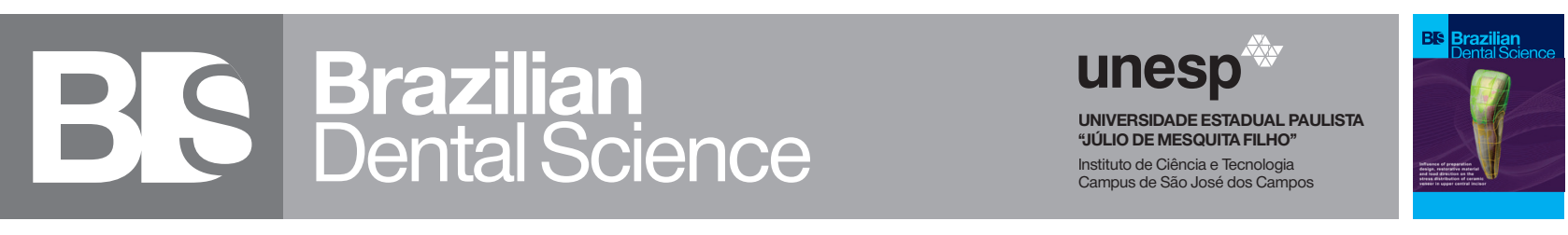

\title{
Awareness, attitude and ethical concern of dental practitioners about stem cells: a cross-sectional study
}

\author{
Consciência, atitude e preocupação ética dos dentistas sobre as células-tronco: um estudo transversal \\ Rayan BAHABRI ${ }^{1}$, Nevine TAYMOUR ${ }^{1,2}$, Mawadh ALI $^{3}$, Ghada ALAHMADI ${ }^{3}$, Ayman MANDORAH ${ }^{4}$, Sary BORZANGY $^{3}$ \\ 1 - Taibah University, Department of Restorative Dental Sciences, Al-Madinah Al-Munawwarah, Kingdom of Saudi Arabia. \\ 2 - Alexandria University, Faculty of Dentistry, Egypt. \\ 3 - Taibah University, Al-Madinah Al-Munawwarah, Kingdom of Saudi Arabia. \\ 4 - Taif University, Taif, Kingdom of Saudi Arabia.
}

\section{ABSTRACT}

Objective: To evaluate the level of awareness and attitude among dental practitioners regarding the use of stem cells in dentistry and to determine their knowledge of ethical concerns related to the recent therapy. Material and Methods: A cross-sectional survey-based study was conducted at Taibah University Dental College and Hospital. Medina and at governmental and private dental clinics at the western region of Saudi Arabia. Responses of dental practitioners who completed the survey were recorded between March 2019 and July 2019 without containing any personal identifiers. Level of awareness and attitude and knowledge about ethical issues in relation to stem cell therapy was established. Results: A total of 214 male and female dental practitioners participated in this study and the majority were registered at the Saudi Commission for Health Specialists 128 (59.8\%). Dental consultants reported the highest percentage of awareness about dental stem cells $(96 \%, p=0.005)$, whereas general dental practitioners $(56.2 \%, \mathrm{p}=0.005)$ and specialists $(52 \%, \mathrm{p}=0.005)$, respectively had a lower percentage. When ethical concerns were determined, dental consultants had the highest percentage of knowledge (56\%, p= $0.005)$, whereas dental practitioners $(71.2 \%$, $\mathrm{p}=0.005)$ with $<5$ years of experience (69.1, $\mathrm{p}=0.002$ ) lacked information about related ethical issues. Conclusion: Ways to increase

\section{RESUMO}

Objetivo: Avaliar o nível de consciência e a atitude dos dentistas em relação ao uso de células-tronco na odontologia, e determinar o conhecimento desses profissionais sobre as questões éticas relacionadas à terapia recente. Material e Métodos: Um estudo transversal baseado em pesquisa foi conduzido na Faculdade e Hospital de Odontologia da Universidade Taibah de Medina e em clínicas odontológicas governamentais e privadas na região oeste da Arábia Saudita. As respostas dos dentistas que responderam à pesquisa foram registradas entre março de 2019 e julho de 2019, sem conter nenhum identificador pessoal. Foi estabelecido o nível de consciência, atitude e conhecimento sobre questões éticas em relação à terapia com célulastronco. Resultados: Um total de 214 dentistas do sexo masculino e feminino participaram deste estudo, sendo $128(59,8 \%)$ desses cadastrada na Comissão Saudita de Especialistas em Saúde. Os consultores em odontologia relataram o maior percentual de conhecimento sobre as célulastronco dentárias $(96 \%, \mathrm{p}=0,005)$, enquanto os dentistas gerais $(56,2 \%, \mathrm{p}=0,005)$ e especialistas $(52 \%, \mathrm{p}=0,005)$ tiveram um percentual menor. Quando as questões éticas foram determinadas, os consultores em odontologia tiveram o maior percentual de conhecimento (56\%, $\mathrm{p}=0,005)$, enquanto os dentistas $(71,2 \%, \mathrm{p}=0,005)$ com menos de 5 anos de experiência $(69,1 \%$, $\mathrm{p}=0,002)$ tinham menos informações sobre questões éticas relacionadas. Conclusão: Formas 
stem cell awareness among dental practitioners in this study recommended including stem cell topics in the dental curriculum and organizing frequent seminars and conferences on this subject.

\section{KEYWORDS}

Stem cell; Awareness; Ethical; Dental practitioner. de aumentar a conscientização sobre as célulastronco entre os dentistas deste estudo incluem tópicos sobre células-tronco no currículo de odontologia, além de frequentemente organizar seminários e conferências sobre o assunto.

\section{PALAVRAS-CHAVE}

Célula tronco; Conhecimento; Ética; Dentista.

\section{INTRODUCTION}

S tem cell technology has recently gained wide recognition and acceptance in the field of dentistry. Many studies were conducted to assess the effects of stem cells on the replacement and repair of damaged tooth tissues [1,2].

Stem cells are body cells that have the ability to divide, grow and differentiate into other types of cells during the process of body growth and development. There are two main types, namely, embryonic and adult stem cells, the latter type is mostly involved in many of the ongoing researches on treatment management and tissue repair processes enhanced by these cells [3]. It should be noted that postnatal stem cells, in particular could be easily given by the patient or close relatives [4]. Adult stem cells are dental cells found inside the pulp of deciduous and permanent teeth [5]. They are numerous, easy to collect from deciduous teeth and wisdom teeth which would otherwise be removed. They are also more easily isolated and lack ethical issues. These cells have the potential means to differentiate into odontogenic-like cells and promote the formation of normal dentine like tissue that allow a natural and vital repair process to occur $[5,6]$.

As up to this point, the discovery of stem cells and the great success of their use in many areas of medicine has drawn much of the dentists' attention towards improving traditional dental treatments by using this technology. Their strategy relies on some sort of a biological approach that integrates both tissue engineering designing and molecular biology. This method would potentially enhance the formation of biological tissue replacements that successfully repair and restore the tissues back to their normal structure and function [7].

This updated technology recently attracted much of dentist's interests towards applying it in the field of endodontics as a means of getting better promising answers to many of questionable unresolved cases, such as apical root resorption, open apexes, fractures, immature roots that are not completely developed, as well as cases of severely damaged coronal tooth structure. It should be emphasized that adult stem cells, scaffolds and growth factors are considered crucial elements for the success of the tissue engineering process. [5]

The use of stem cell technology in the dental practice and its major role in regenerative dental treatment approaches would lead to a revolution updates in the field of dentistry that would greatly improve different treatment modalities in the future.

Because of the lack of literature on the different views and opinions by dentists in Saudi Arabia for the use of dental stem cells, the aim of the present study was to evaluate the difference in the level of awareness, attitude and knowledge of ethical concern among practicing dentists at the western region of Saudi Arabia regarding the use of dental stem cells in clinical dental practice.

\section{MATERIAL AND METHODS}

A descriptive, cross-sectional study was conducted at Taibah University Dental College 
and Hospital, Medina and at governmental and private dental clinics at western region of Saudi Arabia. Male and female dentists who were general dental practitioners (GDP), dental board residents, specialists and consultants (registered in Saudi Commission for Health Specialists) were invited to participate in this study. Dentists enrolled outside the western region of Saudi Arabia were excluded from this study, as well as junior undergraduate dental students.

The independent variable in this study was nominal as it included dental specialists, board residents, consultants and general dental practitioners with different sex and years of experience. The dependent variable was the level of awareness, attitude and knowledge of ethical concerns of dentists regarding the use of stem cells in dentistry.

Sample size was calculated using a tool provided online by Center for Disease Control (CDC) [8]. The estimated target obtained from a previous study was used with the expected frequency at 50\%, and the accepted margin of error was 5\% [9]. The estimated sample size of this study was calculated as 262 at 95\% confidence level. From a sample of 262 dentists, a total of 214 participants completed and anonymously returned the questionnaire and were included in this study with a final response rate of $81.67 \%$ while 48 participants were excluded as they failed to return the questionnaire.

A convenient sample was obtained from all dentists who completed and returned the questionnaire.md the sample was divided into separate groups to distinguish the different qualifications of the participants (specialists, consultants, board residents and general dental practitioners). Data was obtained and analyzed from the sample groups.

An anonymous descriptive selfadministered survey was utilized in this study. The research tool was a close-ended questionnaire previously validated, reliedon and used in a previous study published by the Indian Journal of Dental Research with slight modifications to fulfill all the aspects of the current study [9]. The questionnaire was distributed by e-mails and social media and was composed of four sections: Section I: an introductory page; Section II (Q.1-Q.6): included the participant's information as age, sex, area of practice, qualification, registration status in the Saudi Commission for Health Specialties (SCHS), and years of experience. Section III (Q.7- Q.15): included knowledge and awareness about stem cells. Section IV (Q.16-Q.18): focused on sources of stem cells and ethical concerns. Section V (Q.19-Q.20): described attitudes and predictions towards stem cells.

The protocol for this study was approved by the Research Ethics Committee of the College of Dentistry Taibah University (Protocol no.TUCDREC/20181111/Ali) in agreement with the guidelines of Helsinki Declaration. The study was a self-administrative survey-based mainly conducted for research purposes. An introductory page was included to clarify the aim of the study and secure confidentiality of data. All participation was voluntary.

\section{Statistical analysis}

Data was collected using an electronic questionnaire and cleaned to revise utilizers or odd figures, descriptive analysis in terms of central tendency and dispersion or percentage presentation followed by the suitable inferential statistics using the suitable test of significance was made through IBM SPSS Statistics software (version 21, Armonk, New York, USA) at $\mathrm{p} \leq$ 0.05 . Chi- squared test was used to determine the association between awareness, attitude and knowledge of ethical concerns of stem cells with different characteristic variables.

\section{RESULTS}

A total of 214 male and female dentists successfully completed the online questionnaire. The included respondents were general dental practitioners $153(71.5 \%)$ board residents 11 (5.1\%), specialists $25(11.7 \%)$ and consultants 
$25(11.7 \%)$. Majority of participants were males $108(50.5 \%)$ of less than 35 years of age $160(74.8 \%)$ and less than 5 years of clinical experience 139 (65\%). Most of the respondents practiced in governmental dental clinics 170 (79.4\%) and were registered at the Saudi Commission for Health Specialists 128 (59.8\%). Table I presents the demographic characteristics.

Table I - Demographic characteristics of 214 participants successfully completed the self-administered questionnaire

\begin{tabular}{|cc|}
\hline Characteristics & $\mathbf{n}(\%)$ \\
\hline Age (years) & \\
\hline 35 & $160(74.8)$ \\
$35-50$ & $0(0)$ \\
$" 50$ & $54(25.2)$ \\
\hline Sex & \\
\hline Male & $108(50.5)$ \\
\hline Female & $106(49.5)$ \\
\hline Qualification & \\
\hline General Dental Practitioner (GDP) & $153(71.5)$ \\
\hline Board resident & $11(5.1)$ \\
Specialist & $25(11.7)$ \\
Consultant & $25(11.7)$ \\
\hline Experience (years) & \\
\hline «5 & $139(65)$ \\
$5-10$ & $39(18.2)$ \\
"10 & $36(16.8)$ \\
\hline Area of Practice & \\
\hline Private clinic & $44(20.6)$ \\
\hline Governmental clinic & $170(79.4)$ \\
\hline Registration at SCFHS & $128(59.8)$ \\
\hline Yes & $86(40.2)$ \\
\hline No & \\
\hline
\end{tabular}

A significant association was found between qualification of participants and their awareness of regeneration and tissue engineering $(\mathrm{p}=0.006)$. All board residents $11(100 \%)$ and a high percentage of consultants 24 (96\%) were aware of the concept of tissue engineering, followed by general dental practitioners 108 (70.6\%), and specialists 16 (64\%), respectively. A significant association was also found between qualification of participants and their awareness about stem cells in general $(p=0.014 \%)$.
Regarding this issue, all dental consultants 25 (100\%) and board residents 11 (100\%) were aware about stem cells, followed by general dental practitioners 117 (76.5\%) and specialists 19 (76\%), respectively. Furthermore, there was a significant association between participant's qualifications and awareness about dental stem cells $(\mathrm{p}=0.005)$. A high percentage of dental consultants 24 (96\%) and board residents $10(90.9 \%)$ were aware of dental stem cells, followed by general dental practitioners 86 (56.2\%) and specialists 13 (52\%), respectively. Table II demonstrates the association between participant's qualification and awareness about stem cells.

Table II - Association between participant's qualification and awareness about stem cells

\begin{tabular}{|c|c|c|c|c|c|c|}
\hline \multirow{3}{*}{ Qualification } & \multicolumn{6}{|c|}{ Variable } \\
\hline & \multicolumn{2}{|c|}{$\begin{array}{l}\text { Awareness } \\
\text { about regenera- } \\
\text { tion and tissue } \\
\text { engineering }\end{array}$} & \multicolumn{2}{|c|}{$\begin{array}{l}\text { Awareness } \\
\text { about stem } \\
\text { cells in general }\end{array}$} & \multicolumn{2}{|c|}{$\begin{array}{l}\text { Awareness } \\
\text { about dental } \\
\text { stem cells }\end{array}$} \\
\hline & $\begin{array}{c}\text { Yes } \\
\text { n(\%) }\end{array}$ & $\begin{array}{c}\text { No } \\
\mathrm{n}(\%)\end{array}$ & $\begin{array}{c}\text { Yes } \\
\text { n(\%) }\end{array}$ & $\begin{array}{c}\text { No } \\
\mathrm{n}(\%)\end{array}$ & $\begin{array}{c}\text { Yes } \\
\mathrm{n}(\%)\end{array}$ & $\begin{array}{c}\text { No } \\
\text { n(\%) }\end{array}$ \\
\hline Specialist & $16(64)$ & $9(36)$ & $19(76)$ & $6(24)$ & $13(52)$ & $12(48)$ \\
\hline Consultant & $24(96)$ & $1(4)$ & $25(100)$ & $0(0)$ & $24(96)$ & $1(4)$ \\
\hline Board & $11(100)$ & $0(0)$ & $11(100)$ & $0(0)$ & $10(90.9)$ & $1(9.1)$ \\
\hline GDP & $108(70.6)$ & $45(29.4)$ & $117(76.5)$ & $36(23.5)$ & $86(56.2)$ & $67(413.8)$ \\
\hline$p$-value & 0.006 & & 0.014 & & 0.005 & \\
\hline
\end{tabular}

When ethical issues were considered, dental specialists, board residents and general dental practitioners showed significantly poor knowledge of ethical concerns about stem cells which was prominent among the group of dental practitioners 109 (71.2\%) and few percentages believed no ethical issues $(\mathrm{p}=0.005)$. In the contrary, a satisfactory percentage of dental consultants 14 (56\%) were significantly aware about ethical issues. Moreover, when years of experience were considered, dentists were found to significantly lack information about ethical concerns, much more of interest among dental practitioners 96 (69.1\%) with less than 5 years of experience and few percentages believed no ethical issues $(\mathrm{p}=0.002)$. However, practitioners with more than 10 years of 
practice had significantly equal percentages of knowledge 17 (47.2\%) and lack of knowledge $17(47.2 \%)$ regarding ethical issues. Table III demonstrates association between participant's qualification and experience respectively, with ethical concerns regarding stem cells in dentistry.

Table III - Association between participant's qualification and experience, respectively with the ethical concerns regarding stem cells in dentistry

\begin{tabular}{|c|c|c|c|c|c|c|c|}
\hline \multirow{3}{*}{ Qualification } & \multicolumn{4}{|c|}{ Variable } & \multicolumn{3}{|c|}{ Variable } \\
\hline & \multicolumn{3}{|c|}{ Ethical concern } & \multirow{2}{*}{$\begin{array}{c}\text { Experi- } \\
\text { ence } \\
\text { (years) }\end{array}$} & \multicolumn{3}{|c|}{ Ethical concern } \\
\hline & $\begin{array}{c}\text { Yes } \\
\text { n(\%) }\end{array}$ & $\begin{array}{c}\text { No } \\
\text { n(\%) }\end{array}$ & $\begin{array}{c}\text { Don't } \\
\text { Know } \\
\text { n(\%) }\end{array}$ & & $\begin{array}{c}\text { Yes } \\
\text { n(\%) }\end{array}$ & $\begin{array}{c}\text { No } \\
\text { n(\%) }\end{array}$ & $\begin{array}{l}\text { Don't } \\
\text { Know } \\
\text { n(\%) }\end{array}$ \\
\hline Specialist & $8(32)$ & $2(8)$ & $15(60)$ & & $\begin{array}{c}38 \\
(27.3)\end{array}$ & $5(3.6)$ & $\begin{array}{c}96 \\
(69.1)\end{array}$ \\
\hline Consultant & $14(56)$ & $4(16)$ & $7(28)$ & $<5$ & $9(23.1)$ & $7(17.9)$ & $23(59)$ \\
\hline Board resident & $3(27.3)$ & $3(27.3)$ & $5(45.5)$ & $\begin{array}{l}5-10 \\
>10\end{array}$ & & & \\
\hline GDP & $\begin{array}{c}39 \\
(25.5)\end{array}$ & $5(3.3)$ & $\begin{array}{c}109 \\
(71.2)\end{array}$ & & $17(47.2)$ & $2(5.6)$ & $17(47.2)$ \\
\hline$p$-value & 0.005 & & & $p$-value & 0.002 & & \\
\hline
\end{tabular}

When dental participants were evaluated for their knowledge about stem cell research, all subjects had a significant insufficient information which was highest among general dental practitioners $145(94.8 \%)(\mathrm{p}=0.005)$. In terms of experience, all participants showed significant lack of information about stem cell research which was more prominent among dental practitioners 129 (92.8\%) with less than 5 years of experience $(\mathrm{p}=0.018)$. Regarding stem cell banking, dental consultants 18 (72\%) and board residents 7 (63.6\%) significantly recommended patients to store dental stem cells, whereas, dental specialists 20 (80\%) and general dental practitioners 94 (61.4\%) were significantly not in favor of this issue $(p=0.001)$. Table IV demonstrates association between participant's qualification and experience respectively, with attitude towards knowledge about stem cell research and patient's recommendation to store dental stem cells.
Table IV - Association between participant's qualification and experience respectively, with attitude towards knowledge about stem cell research and patient's recommendation to store dental stem cells

\begin{tabular}{|c|c|c|c|c|c|c|c|}
\hline \multirow{3}{*}{ Qualification } & \multicolumn{4}{|c|}{ Variable } & \multicolumn{3}{|c|}{ Variable } \\
\hline & \multicolumn{2}{|c|}{$\begin{array}{l}\text { Do you enough } \\
\text { about stem cell } \\
\text { research }\end{array}$} & \multicolumn{2}{|c|}{$\begin{array}{l}\text { Will you recom- } \\
\text { mend a patient } \\
\text { to store dental } \\
\text { stem cell }\end{array}$} & \multirow[t]{2}{*}{$\begin{array}{l}\text { Experi- } \\
\text { ence }\end{array}$} & \multicolumn{2}{|c|}{$\begin{array}{l}\text { Do you know } \\
\text { enough } \\
\text { about stem } \\
\text { cell research }\end{array}$} \\
\hline & $\begin{array}{l}\text { Yes } \\
\text { n(\%) }\end{array}$ & $\begin{array}{c}\text { No } \\
\text { n(\%) }\end{array}$ & $\begin{array}{c}\text { Yes } \\
\text { n(\%) }\end{array}$ & $\begin{array}{c}\text { No } \\
\text { n(\%) }\end{array}$ & & $\begin{array}{l}\text { Yes } \\
\text { n(\%) }\end{array}$ & $\begin{array}{c}\text { No } \\
\text { n(\%) }\end{array}$ \\
\hline Specialist & $3(12)$ & $22(88)$ & $5(20)$ & $20(80)$ & \multirow{4}{*}{$\begin{array}{l}>5 \\
5-10 \\
<10\end{array}$} & $10(7.2)$ & $\begin{array}{c}129 \\
(92.8)\end{array}$ \\
\hline Consultant & $9(36)$ & $16(64)$ & $18(72)$ & $7(28)$ & & & \\
\hline Board & $5(45.5)$ & $6(54.5)$ & $7(63.6)$ & $4(36.4)$ & & $7(17.9)$ & $\begin{array}{c}32 \\
(82.1)\end{array}$ \\
\hline GDP & $8(5.2)$ & $\begin{array}{c}145 \\
(94.8)\end{array}$ & $\begin{array}{c}59 \\
(38.6)\end{array}$ & $\begin{array}{c}94 \\
(61.4)\end{array}$ & & $\begin{array}{c}8 \\
(22.2)\end{array}$ & $\begin{array}{c}28 \\
(77.8)\end{array}$ \\
\hline$p$-value & 0.005 & & 0.001 & & $p$-value & 0.018 & \\
\hline
\end{tabular}

Further analysis of the present data showed that an average of $83.9 \%$ of all participants recommended including stem cell topics in the dental curriculum and no significant difference was found between qualifications and the preference $(\mathrm{p}=0.064)$. It was found that an average of $90.6 \%$ of all participants encouraged stem cell research with no significant difference between qualifications and the preference $(\mathrm{p}=$ 0.515). An average of $94.4 \%$ of all participants in this study predicted promising future for stem cell research in Saudi Arabia with no significant difference between qualifications and the preference $(\mathrm{p}=0.546)$.

Data analysis further revealed that a total of $57 \%$ of the information about stem cells was taken from television sources, commercial companies and magazines with frequency distribution of $19 \%$ each, respectively. This was followed by dental schools (14\%), professionals and journals (10\% each) and internet source (9\%) in that order. Regarding the recommended ways to increase stem cell awareness, a total of $64 \%$ was gained by attending conferences and continuing education programs (32\% each) respectively, followed by journals (22\%) and advertisements (14\%) in that order. 


\section{DISCUSSION}

The present study provided plenty of information about the awareness of dentists towards the potential use of stem cells. This study targeted dentists in the western region of Saudi Arabia and most of the participants were aware of the use of stem cells in regenerative and tissue engineering treatments, stem cells in general and dental stem cells. In the present study, stem cell recognition was more evident among dental consultants and board residents than specialists and general dental practitioners. This finding might be due to the fact that consultants have advanced clinical practice and treatment plans over other groups of dentists and at the same time, dental board residents have the motivation to fulfill their clinical requirements and skills according to the most updated modalities. The present findings complied with previous studies conducted in different regions of the world, for example, a study conducted in Nigeria reported that $81.0 \%$ of the dental participants were aware about the use of stem cells and other studies in India concluded that a high percentage of dental professionals were fully aware of stem cells [10-12]. These findings indicate that stem cell technology is becoming one of the most challenging topics dominating treatment modalities in the world of medicine and dentistry [10].

Based on the present findings. dental consultants revealed more understanding of the ethical issues about stem cells over other participants, of which board residents, majority of general dental practitioners and specialists lacked the information and some believed no ethical concern. No matter years of experience, a high percentage of dentists in this study reported poor ethical concerns towards stem cells, minor exception was found in those over ten years of dental practice, who were equally divided between knowing and not knowing about the issue. These findings were consistent with a recent study in which $84 \%$ of the involved dental professionals were unaware of the guidelines related to the use of dental stem cells [11]. Accordingly, due to minimum information in literature about ethical concerns of stem cells, more research is required in the future to determine how ethics interact with dental stem cell technology.

Storage of dental stem cells, were recommended in this study by both dental consultants and board residents which complied with previous studies in literature in which most of the practicing dentists recommended dental stem cell banking to their patients for potential treatments $[9,13]$. However, there were differences in opinion in the present study with general dental practitioners and dental specialists as they did not advise for stem cell storage. These variations in attitude would emphasize the importance of putting more efforts in future research to increase knowledge and updates of dental professionals on dealing with stem cellbased technology. which is expected to grow and generate new discoveries, therapies, and patient outcomes in the future.

Most of the participants of this study had poor knowledge about stem cell research with no significant difference between qualification and preference to gain or update knowledge $(\mathrm{p}=$ 0.290). Comparable results were seen in a survey based study conducted on recent graduates of dental schools in Saudi Arabia reported poor to moderate knowledge about stem cell research [14]. Consistent results were also found with other studies which disclosed poor knowledge of stem cells among dentists and dental students in a cross-sectional study conducted in Nigeria $[10,15]$. Furthermore, when considering years of experience, all the participants in this study revealed poor knowledge about stem cell research no matter years of clinical practice. Other previous studies concluded that dentists with more than five years of experience had more knowledge about stem cell research than those with less years of experience [10]. However, this was not exactly the case in the present study.

According to various predictive measures disclosed in this study, a high tendency of the participants suggested stem cell topics to be included in dental curriculum to promote predictions toward stem cell recognition. This finding complied with previous studies which 
recommended that topics in relation to stem cell and regenerative dentistry be covered in both undergraduate and post graduate dental curricula $[12,15,16]$. Furthermore, more than $90 \%$ of the participants in this study highly recommended to carry out stem cell research in Saudi Arabia and a higher proportion reassured of a favorable and positive future. This finding coincided with a recent study conducted in India in which participants highly believed of the impact of stem cell research and its promising application in dentistry [17].

The main channels of information cited in this study originated mostly from television sources and advertisements from commercial companies and magazines. This reflected the amount of strength and power these systems have on the continuous rise of stem cell technology that recently challenged dental treatment modalities. The second source of information was notably derived from dental schools, professional societies and journals which influenced the progress of stem cells in dentistry. Participants in the present study did not use internet connections as a source of information while it was used primarily used in other studies, probably due to the ease of access to these systems [11].

Attending conferences, continuing dental education programs and seminars were the preferred ways to increase stem cell awareness by dental professionals in this study, as these educational routes are usually linked with national and international views of many practitioners of interest from different regions of the world. Journals and advertisements were other means of gaining awareness in this study. These findings coincided with what was obtained in a previous study conducted in India in which most of dental participants encouraged the concept of attending seminars and symposiums as an effective way of learning about stem cells [16].

Study limitations: First limitation was that participants were recruited using a convenient sample type which could limit the generalizability of the results. A second limitation was that questions related to the ethical concerns of stem cells were generalized and may not give a complete assessment of the issue.

\section{CONCLUSION}

Data from the present study revealed significant high level of awareness about stem cells among all dental participants in which consultants and board residents were on the lead. However, there was lack of information about the ethical concerns that was significantly higher among the group of general dental practitioners with less than five years of clinical experience. Within a similar context, all participants of the present study had poor knowledge regarding stem cell updates and research, which was evident among practitioners with less than 5 years of dental practice. Therefore, due considerations should be given to increase and empower better understanding of the concept and use of stem cells by dental practitioners from all dimensions including improvement in knowledge about research studies and ethical concerns. Moreover, this study revealed some differences in opinion regarding stem cell storage which was recommended by dental consultants and board residents and opposed by dental practitioners and specialists. All dental professionals in the present study encouraged the inclusion of stem cell topics in the curriculum of dental schools and suggested organizing frequent seminars and conferences to cope with the continuous updates happening in stem cell technology. Positive predictive measures were further presented in this study by the high percentage of practitioners who encouraged conduction of stem cell research in Saudi Arabia and believed in its promising future as well. These vital considerations are expected to raise and update knowledge and shape ethical concerns among dentists with the growing stem cell technology. The present study can ultimately be used as a guideline for evaluating the level of stem cell awareness, attitude and ethical concerns of dental professionals in Saudi Arabia. More research is required to handle these issues in the future. 


\section{Disclosure}

Authors have no conflict of interest, and the study was not supported or funded by any institution.

\section{Acknowledgment}

We are thankful to the General Authority for Statistics for their assistance with data acquisition. In addition, we have to express our appreciation to Dr. Orange groups for their valuable contribution with questionnaire distribution to a wide range of dental practitioners.

\section{Funding}

The author(s) received no specific funding for this work.

\section{Conflict of interest}

The authors have no proprietary, financial, or other personal interest of any nature or kind in any product, service, and/or company that is presented in this article.

\section{Regulatory Statement}

This study was conducted in accordance with all the provisions of the local human subject's oversight committee guidelines and policies of: Taibah University, College of Dentistry Research Ethics Committee. The approval code for this study is: TUCDREC/20181111/Ali.

\section{REFERENCES}

1. Sonoyama W, Liu Y, Yamaza T, Tuan RS, Wang S, Shi S, et al. Characterization of the apical papilla and its residing stem cells from human immature permanent teeth: a pilot study. J Endod. 2008;34(2):166-71.

2. Mason C, Dunnill P.A brief definition of regenerative medicine. Regen Med. 2008 Jan;3(1):1-5. doi: 10.2217/17460751.311. PMID: 18154457.
3. Mao JJ. Stem cells and the future of dental care. NY State Dent J. 2008;74(2):20-4.

4. Sandhu SS, Nair M. Stem cells: potential implications for tooth regeneration and tissue engineering in dental science. People J Sci Res. 2009;2(1):41-5

5. Gandhi A, Gandhi T, Madan N. Dental pulp stem cells in endodontic research: a promising tool for tooth tissue engineering. Rev Sul-Bras Odontol. 2011;8(3):335-40.

6. Kumar MSR, Varma KM, Satish RK, Nanduri RMK, Raju SMK, Rao M. Stem cells in endodontic therapy. Int J Med Res Heal Sci. 2014;3(4):977-83.

7. Langer R, Vacanti JP. Tissue engineering. Science. 1993 May 14:260(5110):920-6. doi: 10.1126/science.8493529.PMID: 8493529

8. OpenEpi [Internet]. Dean AG, Sullivan KM, Soe MM. Open source epidemiologic statistics for public health [cited 2021 Mar 19]. Available from: https://www.openepi.com/Menu/OE_Menu.htm.

9. Katge F, Shetty AJ, Rusawat B, Vamsi KC. Knowledge and attitude of Indian dentists regarding dental stem cells: a cross-sectional descriptive survey. Indian J Dent Res. 2017;28(4):367-74.

10. Sede MA, Audu 0, Azodo CC. Stem cells in dentistry: knowledge and attitude of Nigerian dentists. BMC Oral Health. 2013;13:27.

11. Chitroda P, Katti G, Attar N, Shahbaz S, Sreenivasarao G, Patil A. Stem cells in dentistry: a study regarding awareness of stem cells among dental professionals. Indian J Dent Res. 2017;28(6):711-6.

12. Jose N. Assessment of knowledge, attitude, and practice regarding applications of stem cells in dentistry among dental house surgeons, postgraduate students, and teaching faculties in two dental colleges in Ernakulam, Kerala, India. Int J Oral Care Res. 2018;6(1):65-8.

13. Basson R, Moodley D, Oliviera A, Basson N. A survey of the opinions of dentists regarding stem cells in dentistry. South African Dent. J. 2016;71(8):351-5.

14. Alhadlaq A, Al-Maflehi N, Alzahrani S, AlAssiri A. Assessment of knowledge and attitude toward stem cells and their implications in dentistry among recent graduates of dental schools in Saudi Arabia. Saudi Dent J. 2019;31(1):66-75

15. Sede M, Audu 0, Azodo C. Nigerian dental students permissive tendency to the proposed organized incorporation of stem cells application into dental curriculum: a cross-sectional study. J Oral Res Rev. 2016;8(2):72.

16. Bhatt R, Bhatt A, Gurjar D, Dave L. Evaluating awareness on dental pulp stem cells and its applications amongst graduating dental students of Ahmedabad and Gandhinagar district: a cross-sectional survey. Adv Hum Biol. 2014;4(3)54-9.

17. Nagraj A, Acharya S. Perception of dental scientists and post-graduate students regarding future prospects of stem cells in dentistry. Acta Stomatol Croat. 2013;47(4):312-21

\section{Rayan H. Bahabri} (Corresponding address)

Department of Restorative Dental Sciences, Taibah University, Janadah Bin Umayyah Road، Tayba, Medina 42353, Kingdom of Saudi Arabia Date submitted: 2020 Sep 11 Email: rayanhb@gmail.com Accept submission: 2020 0ct 28 